\title{
A Associação das Paneleiras de Goiabeiras (APG): elementos para compreender o capital social e a cultura política*
}

\author{
The Association of the Paneleiras de Goiabeiras (APG): elements to \\ understand social capital and political culture
}

La Asociación de las Paneleiras de Goiabeiras (APG): elementos para entender el capital social y la cultura política

\section{Marcelo de Souza Marques}

Doutorando em Sociologia pela Universidade Federal do Rio Grande do Sul (UFRGS). Membro do Grupo de Pesquisa, Associativismo, Contestação e Engajamento (GPACE-UFRGS) e do Grupo de Pesquisa Núcleo Participação e Democracia (NUPAD-UFES) Bolsista do Conselho Nacional de Desenvolvimento Científico e Tecnológico (CNPq). E-mail: marcelo.marques.cso@gmail.com

\section{Luiz Henrique Rodrigues}

Bacharel, licenciado e Mestre em Ciências Sociais (UFES). Pesquisador Colaborador do Projeto Jongos e Caxambus: Cultura Afro-brasileiras no Espírito Santo. Pesquisador colaborador do Núcleo de Estudos Afro-Brasileiros (NEAB-UFES). Assessor Especial da Gerência de Memória e Patrimônio SECULT-ES. E-mail: luizhrodrig@gmail.com

\section{Rachel Franzan Fukuda}

Mestre em História Social das Relações Políticas pela Universidade Federal do Espírito Santo (UFES). Email:rfranzan@gmail.com.br

\footnotetext{
* Agradecemos à Superintendência do Instituto do Patrimônio Histórico e Artístico Nacional (IPHAN) do Espírito Santo pela liberação de dados da Pesquisa Etnográfica sobre o Ofício das Paneleiras de Goiabeiras - ES, pesquisa da qual participamos entre os anos de 2014 e 2015 como parte de sua primeira equipe. Igualmente, agradecemos aos três pareceristas anônimos da Simbiótica pelas críticas e observações apresentadas.
} 


\section{Resumo}

O objetivo deste artigo é refletir sobre a mobilização de capital social e o desenvolvimento de uma cultura política associativo-participativa em torno da Associação das Paneleiras de Goiabeiras (APG), VitóriaES. A hipótese sustenta que o processo de criação da APG não logrou sucesso na mobilização de capital social e pouco contribuiu para o desenvolvimento de práticas participativas no interior da instituição, que, a princípio, poderiam proporcionar maior envolvimento e identificação dos associados com a APG. A metodologia utilizada consistiu em técnicas qualitativas, especificamente por meio de pesquisa bibliográfica e de entrevistas em profundidade. Os resultados indicam que o processo de construção da APG impactou negativamente no capital social local, gerando uma percepção de "desconfiança institucional" e "baixo associativismo/envolvimento" em relação à associação.

Palavras-chave: capital social; cultura política; Associação das Paneleiras de Goiabeiras (APG).

\section{Introdução}

A construção da Associação das Paneleiras de Goiabeiras (APG), em 25 de março de 1987, resultou de complexas interações entre as Paneleiras, atores e instituições estatais. No calor das lutas e articulações políticas em torno da preservação, do acesso e da extração da argila utilizada do processo produtivo das panelas de barro em Goiabeiras, bem como da concorrência no mercado cultural local de produção de panela de barro, sobretudo com relação aos artesãos de Guarapari $^{1}$, a APG se tornou o principal instrumento de organização dos sujeitos e o canal de comunicação com a esfera institucional. Contudo, ao voltarmos aos sentidos atribuídos pelos sujeitos à APG, com indagações acerca dos significados da APG para as Paneleiras e artesãos, contribuições/benefícios da APG no dia a dia do trabalho dos associados e à avaliação da APG pelos sujeitos, deparamo-nos com significados que identificam a APG limitada ao "local de trabalho", à “estrutura física do Galpão da APG” e à "garantia de renda/trabalho".

Inicialmente, essas indagações eram temas que apenas perpassavam os objetivos centrais de nossos trabalhos autorais e da pesquisa de Revalidação do Ofício das Paneleiras realizada pelo Instituto do Patrimônio Histórico e Artístico Nacional (IPHAN) - da qual participamos em sua primeira etapa, entre os anos de 2014 e 2015. Durante nossas idas e vindas a campo, tais questões passaram a nos chamar a atenção ao percebemos que os sentidos hoje atribuídos pelos sujeitos à APG poderiam ter uma relação com o processo de construção/associação. A partir daí, nosso objetivo passou a ser a retomada e a problematização das interações políticas verificadas

\footnotetext{
${ }^{1}$ Como destacam Marques e Caloti (2013), a relação concorrencial entre as Paneleiras de Goiabeiras e os artesãos de Guarapari, criada a partir dos anos 1980-1990, não se limita a uma dimensão puramente econômica. Há questões culturais e políticas que não podem ser desconsideradas ou colocadas em segundo plano, uma vez que a panela de barro não se resume a um produto econômico; é também um bem cultural atravessado de lado a lado por relações de poder.
} 
durante o processo de construção da APG refletidas à luz da mobilização de capital social e das possibilidades de criação de uma cultura política associativo-participativa em torno da instituição, ao longo de seus pouco mais de trinta anos de existência.

Para levarmos a cabo o estudo, nos guiamos por uma orientação de pesquisa indiciária ${ }^{2}$. Sem o objetivo de adentrar em um debate sobre as diferentes perspectivas e usos do indiciarismo ${ }^{3}$, limitamos nossa concepção da pesquisa indiciária na perspectiva de uma orientação investigativa. Enquanto tal, o indiciarismo se apresenta com uma orientação do olhar do pesquisador para os detalhes, para os fatos marginais que rondam e constituem as relações sociais ${ }^{4}$. A partir dessa orientação, atentamo-nos tanto aos sentidos evocados pelos sujeitos em entrevistas, quanto aos elementos narrativos encontrados na literatura especializada sobre o período histórico referente à construção da APG, para problematizarmos o atual contexto que envolve as relações dos sujeitos com a Associação. Com relação ao instrumental de pesquisa, mobilizamos a pesquisa bibliográfica, a observação direta e, principalmente, a entrevista em profundidade. Ao todo, entrevistamos 14 Paneleiras entre aquelas que trabalham no interior do Galpão e aquelas que mantêm sua produção no ambiente residencial, também conhecidas como “Paneleiras de Quintais”. Com relação aos políticos e gestores, entrevistamos Vitor Buaiz, exprefeito de Vitória à época da construção da APG, J. F. ${ }^{5}$, assistente social da Prefeitura Municipal de Vitória que atuou junto à APG entre finais dos anos 1980 e início dos anos 1990, T. C. A, ex-Superintendente da $6^{\mathrm{a}}$ Sub-Regional do IPHAN no Espírito Santo, P. B, então Gerente de Patrimônio Histórico Cultural da Prefeitura Municipal de Vitória, e F. R. C., então Subsecretário da extinta Secretaria Municipal de Turismo, Trabalho e Renda (SEMTTRE), Secretaria que atuava diretamente junto à APG.

Nossa hipótese é de que o processo de interações políticas envolvendo os atores sociais (Paneleiras) e estatais em torno da construção da APG, entre o final de 1980 e os primeiros anos da década seguinte, não mobilizou suficientemente o capital social existente nas relações

\footnotetext{
${ }^{2}$ No século XIX, a "pesquisa indiciária" ou "indiciarismo", teve em Giovanni Morelli, médico italiano, um de seus principais expoentes. O método morelliano consistia na análise de falsificações em obras de arte e se baseava na observação de minúcias e de traços pictóricos que muitos consideravam de menor expressão. Esse método, contudo, não ficou restrito aos trabalhos de Morelli: o método morelliano "passou a transitar em diversas esferas das ciências humanas e sociais" (Rubião, 2012:13). Nas últimas décadas, a proposta foi resgatada e discutida de forma mais expressiva pelo historiador italiano Carlo Ginzburg (1989).

${ }^{3}$ Para um estudo sobre o indiciarismo enquanto "paradigma indiciário", ver Rodrigues (2005) e Pulice, Monson e Zelis (2012). Para uma leitura do indiciarismo enquanto método, ver Coelho (2007). Já enquanto "orientação de pesquisa", ou instrumental metodológico, conferir Marques e Caloti (2013).

${ }^{4}$ Ao nos referimos ao termo "orientação", posicionamo-nos ceticamente ao indiciarismo enquanto um constructo teórico-metodológico próprio - enquanto campo, nos termos de Bourdieu (2003). Não por simplesmente não concordarmos que este seja um constructo teórico-metodológico próprio, mas por não encontrarmos tal constructo na literatura.

${ }^{5}$ Seguindo os acordos do "Termo de consentimento livre e esclarecido", trabalharemos apenas com abreviações.
} 
estabelecidas pelos sujeitos no contexto de Goiabeiras para uma forma de envolvimento institucional-participativo junto à APG, que, a princípio, poderia proporcionar uma “identificação político-administrativa” dos associados em relação à Associação. Com isso, o que percebemos hoje é uma percepção de "insatisfação/desconfiança institucional” e forte indício de "baixo associativismo/envolvimento institucional" entre os associados, o que pode ajudar a identificar algumas causas das dificuldades no desenvolvimento de ações públicas, ou "semipúblicas", que visam ao desenvolvimento, ao fortalecimento da APG e ao próprio crescimento local.

Vale frisar que ao partirmos de uma análise discursiva e ao propormos trabalhar com as categorias "insatisfação/desconfiança institucional" e "baixo associativismo/envolvimento institucional", buscamos uma proposta de pesquisa qualitativa para compreendermos o capital social e a cultura política. Ademais, para a elaboração desta proposta, também consideramos uma particularidade com relação ao sistema de associação dos sujeitos à APG.

A particularidade diz respeito aos mecanismos informais que envolvem o status de associado. Embora não esteja instituído no Estatuto da APG, elaborado em 1987, há uma espécie de "acordo informal" entre os sujeitos que condiciona a garantia do acesso à matéria-prima (argila) ${ }^{7}$, a possibilidade de concorrer a uma das 32 bancadas do atual Galpão (ou de mantê-la) e a obtenção de benefícios diversos à situação de associado. Esse acordo atua como uma espécie de "dispositivo coercitivo de associação": caso o sujeito não seja associado ${ }^{8}$ ou não esteja em dia com a taxa cobrada da APG, não terá acesso à matéria-prima, não poderá concorrer às bancadas dentro do Galpão, bem como deixará de ter acesso a todos os benefícios que a APG possa dispor, tais como embalagens, camisetas, aventais, dentre outros ${ }^{9}$. Por esse prisma, percebemos que não ser associado não é necessariamente uma opção, o que poderia impactar uma análise quantitativa, pois, afinal, todos são associados e, em uma primeira análise, todos, de alguma

\footnotetext{
${ }^{6}$ Referimo-nos especialmente ao Serviço Brasileiro de Apoio às Micro e Pequenas Empresas (SEBRAE) que, a partir dos anos 1990, passou a atuar fortemente junto à APG visando o fortalecimento do associativismo e a Indicação Geográfica (IG) do ofício.

${ }^{7}$ A argila é extraída por associados imbuídos dessa função e vendida aos demais associados a um valor de $\mathrm{R} \$ 2,50$ a bola (estamos a tomar o ano de 2015 como referência). Cada bola de barro, segundo os sujeitos, é suficiente para fazer duas panelas com tampas, com capacidade de preparo de uma moqueca para três pessoas - a "unidade de medida" mais comum usada pelos sujeitos para se referir à dimensão da panela é dada pela quantidade de pessoas que ela serve no preparado da moqueca capixaba, prato típico da culinária local. Após a extração, as bolas de barro são transportadas até o Galpão com auxílio da Prefeitura Municipal de Vitória, que fornece um caminhão baú de pequeno porte, e vendidas aos associados que estão em dia com a APG.

${ }^{8}$ Não ser associado não é uma opção no contexto das Paneleiras de Goiabeiras. Todos os sujeitos que produzem panelas de barro em Goiabeiras são associados à APG. Isso porque, formalmente, nenhuma pessoa que não seja associada à APG tem acesso ao barro utilizado pelas Paneleiras - há relatos de desvio de matéria-prima para outros núcleos de produção de panelas de barro no contexto capixaba.

${ }^{9}$ Em campo, vimos, contudo, que não raramente os sujeitos inadimplentes burlam esse "sistema", conseguindo a argila e demais vantagens com parentes e amigos que também são Paneleiras ou mesmo diretamente com a Diretoria da APG, ainda que sofram algum tipo de constrangimento, como o "lembrete" de que não estão em dia com a APG.
} 
forma, participam da APG. Dessa forma, cumpre destacar que por "associativismo/envolvimento institucional" entendemos o envolvimento dos associados à vida associativo-participativa junto à instituição, e não a simples condição de "associado". Já no que se refere à "insatisfação/ desconfiança institucional”, compreendemos essa categoria como um indicativo de fraca cultura política associativo-participativa, diretamente vinculada a um processo de baixo grau de “identificação político-administrativa” dos sujeitos com as instituições.

Para melhor exposição das reflexões, além desta introdução, seccionamos o artigo em quatro seções. Na primeira, abordaremos duas das categorias conceituais que mobilizaremos ao longo do artigo, a saber: capital social e cultura política. Na sequência, apresentaremos as principais modificações ocorridas no contexto de Goiabeiras, destacando o deslocamento de muitas Paneleiras, que antes trabalhavam no ambiente doméstico para o interior do Galpão da APG. Na terceira seção, focaremos o contexto de criação da APG, identificando os conflitos, os atores relevantes e os limites de ações dos poderes público e "semipúblico" posteriores à criação da Associação. Por fim, apresentaremos nossas considerações, as quais sustentam que a forma como foi conduzido e estruturado o processo de criação da APG não mobilizou suficientemente o capital social existente no grupo no sentido de um envolvimento institucional-participativo junto à APG. Ademais, a forma como se deu a organização institucional da Diretoria da Associação, por muitos anos limitada a um revezamento de sujeitos de uma mesma família, e a divisão do grupo após a formação da APG ("Paneleiras do Galpão" e "Paneleiras de Quintais") foram fatores que ajudaram a compreender o grau geral de "insatisfação/desconfiança institucional" e de "baixo associativismo/envolvimento institucional" por parte do grupo das Paneleiras de Goiabeiras Velha.

\section{Capital social e cultura política: esclarecendo pressupostos}

Capital social e cultura política são conceitos que dificilmente se separam. Ambos destacam as relações entre sujeitos em um determinado momento e espaço, como confiança (institucional e interpessoal), laços de solidariedade e as formas como os sujeitos atuam em grupo (cultura política participativa, cívica, etc.).

Com relação à ideia de capital social, tomamos tal conceito a partir de sua potencialidade transdisciplinar. Essa potencialidade, ao mesmo tempo em que destaca sua capacidade heurística, também abre margem para críticas que entendem se tratar de um conceito demasiado fluido ou impreciso. 
Entre as críticas à operacionalização do conceito, podemos destacar o trabalho de Bruno Pinheiro W. Reis (2003). De uma forma geral, Reis destaca a falta de mensuração empírica do capital social, sobretudo em relação ao trabalho de Putnam (2000), e de categorias que se fazem presentes na teorização, como confiança. Radicalizando a crítica, o autor indaga "sobre até que ponto a presença de 'capital social' e 'confiança' (interpessoal ou nas instituições) não poderia eventualmente ser vista como manipulação ideológica bem-sucedida" (Reis, 2003:47). De fato, o conceito, portador de uma forte carga normativa, pressupõe a existência de complexas redes interpessoais baseadas em laços de solidariedade primária sustentadas por forte adesão às normas de reciprocidade, pouco problematizando o contex to estratégico dessas relações.

Todavia, mesmo diante das críticas, o conceito de capital social tem sido mobilizado, pelo menos desde finais dos anos 1980, por diferentes autores e em diferentes áreas do conhecimento, como nos estudos de Putnam (1995; 2000), Bourdieu (1980), Kliksberg (1999) e por Ridl \& Vogt (2003), Lima (2001), Baquero (2003; 2008) e Moisés (2008) no contexto brasileiro. É justamente em sua potência transdisciplinar que encontramos sua capacidade explicativa de fenômenos sociais e o que, acreditamos, permite que diferentes autores, como os supracitados, mobilizem-no em suas abordagens.

Sem o objetivo de adentrar nas especificidades de diferentes autores que se utilizam do conceito, podemos destacar, considerando sua transdisciplinaridade, que capital social indica: a) confiança dos sujeitos nas relações sociais, b) ações coletivas, c) participação em associações (formais ou informais), d) cooperação entre os sujeitos, e) reciprocidade. Tais dimensões conceituais se relacionam aos vínculos sociais, como a confiança interpessoal e o engajamento cívico, mas também à confiança dos indivíduos nas instituições criadas para intermediar as relações sociais, como associações cívicas, partidos políticos, Estado, ou mesmo a própria ideia de "democracia".

Essas dimensões evidenciam que não se trata de um conceito estático, mas de algo potencial (Lima, 2001). Certas ações podem fomentar o capital social ou, como demonstram Riedl e Vogt (2003), diminuí-lo. Também não se trata de um conceito determinista, em que o contexto social determina o desempenho das instituições sem que estas também impactem as interações sociopolíticas dos sujeitos entre estes e as instituições. Putnam (2000:191; 194) já havia destacado essas questões ao apresentar três lições da experiência italiana: "o contexto social e a história condicionam profundamente o desempenho das instituições [...] mudando-se as instituições formais pode-se mudar a prática política [...] a história institucional costuma evoluir lentamente". 
Considerando as cinco dimensões do conceito de capital social que destacamos, a definição de Lima (2001:46) se apresenta como um interessante instrumento interpretativo, considerando o capital social como um "conjunto de normas de reciprocidade, informação e confiança presentes nas redes sociais informais desenvolvidas pelos indivíduos em sua vida cotidiana, resultando em numerosos benefícios diretos ou indiretos, sendo determinante na compreensão da ação social"'.

Ao contrário de Reis (2003:47), longe de ser uma "manipulação ideológica bemsucedida", entendemos, como base em Baquero (2003:94), que o capital social "tem possibilitado reflexões alternativas teórico-práticas, conceituações e pesquisas empíricas que permitem que várias áreas de políticas públicas sejam melhor compreendidas”. Não faz parte de nossos objetivos propor desenhos de políticas públicas para o contexto das Paneleiras de Goiabeiras Velha - tal esforço não está ao alcance de um artigo. Limitamo-nos à reflexão sobre as possíveis causas para os indícios de "insatisfação/desconfiança institucional" e de "baixo associativismo/envolvimento institucional" entre os associados da APG e sobre as causas das dificuldades no desenvolvimento de ações públicas, ou "semipúblicas", que visem ao desenvolvimento e ao fortalecimento da associação. Acreditamos que essas reflexões podem lançar novas pistas para se pensar em ações futuras com o intuito de fomentar o associativismo e a participação entre os associados junto à APG, buscando tanto o fortalecimento da instituição, como fomentando o desenvolvimento local, uma vez que a produção de panela de barro envolve um significativo número de famílias da localidade.

Assim como ocorre com o capital social, o conceito de cultura política, entendido como uma "orientación psicológica hacia objetos sociales. Cuando hablamos de la cultura política de una sociedad, nos referimos al sistema político que informa los conocimientos, sentimentos y valoraciones de su población" (Almond; Verba, 1970:30), apresenta certa amplitude, o que também tem gerado críticas quanto a suas possíveis ambiguidades.

Entre as críticas ao conceito de cultura política em Almond e Verba (1970), interessa-nos duas em particular ${ }^{10}$. A primeira refere-se ao modelo de democracia e de cultura política presente na abordagem dos autores. Como destaca Rennó (1998), os críticos argumentam que Almond e Verba têm como ponto de partida e de chegada o "norte global", isto é, as sociedades industrializadas estruturadas em um modelo democrático liberal. Segundo os críticos, ao pensarem a cultura cívica, os autores apresentam a democracia vivenciada no contexto angloamericano "como base para todas as análises e comparações, o que impõem um viés

\footnotetext{
${ }^{10}$ Para uma análise sobre diferentes críticas à noção de cultura política em Almond e Verba (1970), ver Rennó (1998)
} 
metodológico a favor desse modelo em detrimento de outros e dificulta a análise das peculiaridades de cada país" (Rennó, 1998:85).

A pertinência da crítica nos leva a uma consciente recusa de um modelo de cultura política a ser seguido. Quando nos referirmos à cultura política, não estamos a pensar a partir de uma escala valorativa, tampouco em uma comparação entre "cultura política local" (Goiabeiras Velha) e "cultura política cívica" (pautada no ideário democrático ocidental). Nas trilhas de Lane (apud Rennó, 1998:85-86), compreendemos a "utilização da categoria de cultura política não como um esquema classificatório, mas como um método de análise de certo grupo, tentando articular um modelo de interpretação da sua rede de crenças". É nesse sentido que refletiremos sobre e a partir do contexto de Goiabeiras; se falamos de "participação" e "associativismo" não é porque partimos do ideal "cívico" das democracias liberais, e sim porque tais "atitudes coletivas" surgiram no discurso dos sujeitos ao remontarem a sua história.

A segunda crítica que julgamos condizente com o nosso estudo se refere à relação entre cultura política e estrutura política. Recorrendo novamente a Rennó, percebemos que essa relação é apontada como foco de debates entre as perspectivas neo-institucionalistas e culturalistas. Afinal, a cultura política é causa ou efeito da estrutura política? Dentro da discussão apresentada por Rennó, estamos em acordo com as perspectivas que compreendem essa relação como causalidade cruzada, ou seja, há uma “incidência mútua”. Esse argumento é aqui assumido ao partirmos do pressuposto relacional de que a esfera institucional e esfera societal são instâncias altamente correlacionadas: as ações de atores e instituições estatais (estrutura política em um sentido mais genérico) podem provocar "efeitos institucionais" sobre a estrutura organizacional e formas de ação dos atores e organizações civis, da mesma forma que as ações desses, ainda que não alocadas na estrutura política, podem provocar "efeitos de deslocamentos" sobre a estrutura.

Em um sentido relativamente próximo, Moisés (2008) argumenta que cultura política e estrutura política se influenciam mutuamente, sendo ao mesmo tempo causa e efeito. Neste processo, as atitudes, crenças e valores políticos relacionados à noção de cultura política, podem sofrer mudanças a partir do envolvimento de atores e organizações civis nas e com as instituições, da mesma forma que valores, normas, regras das instituições podem ser modificadas a partir das interações com os atores societários.

É a partir desta leitura de capital social e de cultura política que temos problematizado nossa hipótese. Pelo exposto sobre essas categorias, estamos cientes de que podem surgir possíveis indagações sobre a viabilidade da hipótese, sobretudo com relação à mensuração qualitativa da "desconfiança institucional" e do "baixo associativismo" por nós proposta. 
Acreditamos que um desenho metodológico de pesquisa que faça uso de procedimentos como roteiros de entrevistas e surveys, focando essas duas variáveis a partir de uma dimensão qualiquanti, poderia fornecer novas informações. Ainda assim, consideramos nossa problematização pertinente e frutífera, pois destaca uma discussão ainda não realizada pela literatura relevante sobre as Paneleiras de Goiabeiras: uma discussão sobre "fatos marginais" que julgamos relevantes para uma reflexão sobre o atual contexto da Associação das Paneleiras de Goiabeiras (APG), a qual pode abrir novos horizontes para políticas públicas voltadas para o desenvolvimento e fortalecimento sociopolítico das Paneleiras de Goiabeiras e da APG, bem como para o desenvolvimento local, se considerarmos a relevância (cultural e econômica) dessa atividade para a localidade e, de forma geral, para a cidade de Vitória. Se estivermos corretos, a “insatisfação/desconfiança institucional” e o "baixo associativismo/envolvimento institucional”, entendidas como variáveis intervenientes, deverão ser consideradas para o desenvolvimento de ações que visem a superar o quadro atual, fomentando o desenvolvimento local, o fortalecimento da APG e considerando também a realidade das "Paneleiras de Quintais".

Feitas essas considerações, refletiremos, na próxima seção, sobre o contexto de Goiabeiras, entre os anos de 1960 a 1980, para, na sequência, analisarmos o processo de criação da Associação das Paneleiras de Goiabeiras (APG), entre finais de 1980 e início dos anos 1990.

\section{Relações sociais em Goiabeiras: mudanças em curso}

A produção de panela de barro no território capixaba é de longa data. Um dos primeiros registros históricos a mencionar a produção de artefatos cerâmicos na região foi feito pelo naturalista Saint-Hilaire, em 1815. Em passagem pelo Espírito Santo, o viajante relatou a produção indígena de "caldeira de terracota, de orla muito baixa e fundo muito raso [...] num lugar chamado Goiabeiras, próximo da capital do Espírito Santo" (Saint-Hilaire, 1974:55). Embora não permita falar em "panelas de barro", tal qual a conhecemos hoje, o relato confirma a tradição da produção cerâmica na região.

Até meados dos anos 1900, a região de Goiabeiras era uma área rural, isolada do restante da capital. Havia poucos núcleos familiares. A principal atividade econômica e de subsistência era a pesca, a cata de mariscos e a produção de panela de barro. Nesse período, a região carecia de infraestrutura urbana; a principal rota de locomoção dos sujeitos era o mangue, cortado por pequenas canoas, algo comum até os anos 1950-1960. A produção de panela de barro era transportada para o mercado da Vila Rubim, no centro de Vitória, pelas mesmas embarcações usadas na pesca. As casas apresentavam estrutura simples, com amplos quintais abertos, sem 
qualquer demarcação, como cercas ou muros. Até a construção da APG, em 1987, era nos quintais que se dava todo o processo produtivo e comercial das panelas de barro (Mingo Jr.; 2000; Simão, 2008).

Embora sempre destaquem as dificuldades relacionadas à infraestrutura, ao serem indagados sobre esse período, os sujeitos quase sempre se mostram orgulhosos em retratarem "Goiabeiras Velha", núcleo inicial de ocupação da região hoje conhecida como bairro de Goiabeiras, como uma região pacata, marcada por uma vida simples, embalada pelo ritmo da maré, da cata de marisco e da produção de panela de barro. Como fazem questão de ressaltar, em Goiabeiras Velha todos se conheciam; e ao narrarem as relações estabelecidas no local, fica claro, ainda mais se considerarmos o contexto até os anos 1980, tratar-se de uma comunidade marcada por relações sociais sedimentadas em laços parentais e intrafamiliares, com casamentos entre núcleos familiares distintos, levando a uma noção de família ampla. Isso é ainda mais esclarecedor ao percebermos que, ao todo, são cerca de 10 famílias ampliadas que mantêm o saber-fazer panela de barro em Goiabeiras.

Ao insistirmos sobre o contexto entre os anos 1950 e 1980, buscamos entender um pouco mais sobre as relações de reciprocidade e laços de confianças entre os sujeitos. Nessa busca, um elemento integrador da comunidade se destacou: os campeonatos de futebol de várzea. Os campeonatos, além de serem significados pelos sujeitos como um momento de lazer de toda a comunidade, surgem nas narrativas como uma função especial na comunidade: os jogos, geralmente realizados no fim de semana, basicamente dividiam a comunidade em dois grupos. De um lado, o Três de Maio Futebol Clube e, de outro, o Industrial Futebol Clube ${ }^{11}$. Como a rivalidade entre os times era grande, desentendimentos e até mesmo brigas entre os jogadores em campo era algo comum, mas, como destacam os sujeitos, não chegavam a representar um problema fora da competição esportiva. Assim como o jogo em si, que praticamente interrompia todos os fazeres da comunidade, as atividades em torno do futebol, como os churrascos promovidos após os jogos e a própria preparação para os campeonatos, que exigia certa organização dos moradores, também promoviam a cooperação entre os sujeitos. Em suma, ao mobilizar a comunidade em torno da competição, os jogos promoviam a interação social e fortaleciam os laços de solidariedade entre os sujeitos.

Esses laços de solidariedade, cooperação e reciprocidade entre os sujeitos também se faziam presentes no processo produtivo das panelas de barro. Produzir panelas de barro significava - e certamente ainda significa - mais do que uma atividade econômica, tratava-se,

\footnotetext{
${ }^{11}$ Estes eram os principais clubes, mas havia outros, tais como Esporte Clube Goiabeiras, Esporte Clube Belenense e Boa Vista Futebol Clube.
} 
antes de mais nada, de um sistema social complexo, marcado por relações que perpassavam o fazer e o produto final. Afinal:

(...) fazer panela de barro não é [só] moldar barro: é cristalizar um saber, que por sua vez vem de tradições... De histórias de famílias... De relações... Eu não posso entender só a relação que a Paneleira tem com a panela, pois a panela também não é só panela. Assim, eu tenho que descobrir mil e outras coisas para entender porque fazer panela é importante para a identidade da paneleira (Berger, s/d: 5-6).

Nesse sistema social, a solidariedade, a cooperação e a reciprocidade eram elementos comuns que diminuíam as dificuldades do ofício e colaboravam para o processo interno de identificação como Paneleiras de Goiabeiras. Devido às condições de infraestrutura local à época, tais como ruas sem pavimentação, falta de veículos para o transporte e devido à distância do barreiro ${ }^{12}$, extrair as matérias-primas não era algo fácil. Nessas etapas, assim como em determinados processos de produção, sobretudo durante a queima das peças, as Paneleiras mantinham uma relação de ajuda mútua, bem sistematizada por Simão (2008) no termo "entreajuda":

(...) era frequente a ajuda na fogueira entre as comadres, irmãs, sobrinhas e filhas, configurando formas de solidariedade bastante eficientes para as dinâmicas do trabalho desses grupos familiares. Após a queima e o açoite das peças, etapas finais de todo o processo, as mulheres lavavam suas mãos em uma grande bacia de alumínio, refrescando-se depois de enfrentarem o calor da fogueira e a "dona das panelas" servia um café com polenta para as paneleiras ajudantes de fogueira. Nesse momento eram reafirmados os compromissos de entreajuda, quando as outras paneleiras fossem queimar em seus quintais (Simão, 2008:190. Grifos nossos).

Como se percebe, a "entreajuda" se baseava em relações de solidariedade, reciprocidade e confiança intrapessoal. Ao ajudar uma vizinha, amiga ou familiar já se esperava que, em oportunidade futura, também recebesse ajuda. Também nesse sentido, Bento destaca que:

(...) os laços de afeto e solidariedade eram mais fortes naquela época. Basta lembrar que, na maioria das vezes, a paneleira que ia queimar suas panelas sempre podia contar com a ajuda de outras, as quais deixavam seus afazeres e se dirigiam para o quintal daquela paneleira. No final da queima (fogueira), servia-se um café para todos que participaram da referida atividade. Servia-se café, polenta com coco, aipim cozido em água e sal, canjiquinha com coco, cuscuz, pão caseiro, cará... Era uma festa ajudar na fogueira (Bento apud Simão, 2008:175 [Grifos nossos]).

Essa relação de "entreajuda" se estendia para outras etapas do processo produtivo, configurando-se como algo comum entre os sujeitos, como nos narrou Dona E. C. M:

\footnotetext{
${ }^{12}$ Barreiro é a forma como os sujeitos denominam a jazida de extração da argila utilizada na produção das peças cerâmicas. O barreiro localiza-se em uma área conhecida como Vale do Mulembá, em Joana D’Arc, bairro próximo a Goiabeiras.
} 
Fazia assim, a família marcava, antigamente a presidente, já falecida, Dona Melchiadia, marcava "família tal, que dia que vocês vão no barreiro?", porque sempre foi assim, organizado... Assim, “eu vou hoje, fulano vai não!” (...). Então, lá no barreiro, a gente fazia os mutirões. Família de... Dona Iracy, que era minha mãe, ia nossa irmandade toda, umas quatro, tirava aquele barro que se consumia dentro de um mês (...). Mas antigamente era bom, porque a gente ia lá na casa da prima, como é tudo da geração, “oh nós vamos barreiro sexta-feira, vamos?”. Aí aquela família juntava com a nossa família, entendeu? (...). Aí, o frete... Então nós juntava as duas famílias, o caminhão cobra 200 reais, a família nossa pagava 100 e a outra família pagava 100, e não podia fazer duas viagens, era uma viagem só, entendeu? Então nós se unia pra ir lá tirar aquela matéria que dava um mês; aí trazia, produzia e nisso outras família ia e "oh, fulano vai ir!"... É... Vamos supor, Dona Conceição vai no final dessa semana tirar barro, se eu tivesse com barro que tivesse me dando algum problema, que às vezes a gente pega um barro mais fino, mais grosso, a gente falava com a colega "oh, traz umas 10 bolinhas de barro pra mim?" Então, antigamente... Sabe? Era mais companheiro e... Queimar panela, a gente também ia queimava as panelas, ajudava o outro. Eu não ajudava não, porque era criança. Então eu fazia muito sabe o que? Carregava as panelas, eu carregava (Entrevista cedida em 22 de fevereiro de 2016).

Os relatos, representativos na narrativa de Dona E. C. M, nos transmitem uma imagem bem significativa quanto aos laços sociais naquele contexto. O futebol e o fazer panelas, assim como o carnaval de rua, momento em que as famílias se uniam para festejar pelas ruas do bairro, eram atividades cujos sentidos de cooperação, amizade, reciprocidade e confiança eram compartilhados pela comunidade - há pelo menos duas décadas, os campeonatos de futebol e o carnaval de rua deixaram de apresentar uma regularidade ${ }^{13}$, fato lamentado pelos entrevistados, sobretudo os mais idosos, e que indica que já não mobilizam a comunidade como em décadas anteriores.

Contudo, a partir dos anos 1950-1960, a realidade das famílias de Goiabeiras começou a mudar. Naquele momento, a capital Vitória passou a conviver com uma série de investimentos públicos e privados que dariam novos contornos à cidade. Paulatinamente, a então vila de pescadores e Paneleiras, passou a receber novos fluxos populacionais e sentiu os reflexos da expansão e dos novos investimentos da região. Como destaca Costa (apud Dias, 2006), no ano de 1960, o distrito de Goiabeiras apresentava uma população de 1.402 habitantes, já em meados de 1980 esse número subiu para 65.089 habitantes. No mesmo período, a população de Vitória passou dos 83.840 para 149.984 habitantes.

Goiabeiras chegaria aos anos 1980-90 completamente modificada em relação à sua estrutura de três décadas anteriores (Dias, 2006; Simão, 2008) e, como percebemos na narrativa da paneleira Dona B. C, a região sentiria seus reflexos:

\footnotetext{
${ }^{13}$ A última edição do campeonato ocorreu no ano de 2012, mas já há alguns anos não contava como a mesma mobilização como acontecia até a década de 1980.
} 
$\mathrm{Na}$ época que nós era criança, eu vô falar, modificou muito Goiabeiras. Hoje podemos dizer que virou até uma cidade de Goiabeira; quando eu era criança, Goiabeira ainda era... Não tinha calçamento, não tinha luz (...) era bem poucas casas que tinha aqui, era contada assim um grupo... Esse bairro aqui só mora a família dos "Corrêas", esse só mora dos "Fernandes", esse só de "Jesus" (...) Mas Goiabeiras Velha era um bairro, assim, pequeno, legal de se morar. Vou falar que hoje não é... que é... eu moro aqui até hoje que eu gosto, mais já foi melhor de se morar, tá (...). O convívio [entre os moradores] era bem melhor do que é hoje, porque hoje, veio muita gente estranha mora aqui no bairro de Goiabeiras... E eu acho que essa vinda de pessoas estranhas pra aqui já tem mais de uns trinta anos que veio o pessoal estranho pra cá, pra Goiabeiras (...). É isto, porque, aqui em Goiabeiras todo mundo conhecia um o outro, agora você vê cada pessoa estranha que passa aqui no bairro, que pergunta: quem é aquele ali? Você: "num sei!" (Entrevista cedida aos 29 de fevereiro de 2016).

\section{Dos Quintais para o Galpão: mudanças no sistema social das Paneleiras}

Até a década de 1980, o sistema produtivo de panelas de barro em Goiabeiras ainda se concentrava nos quintais das casas das famílias de Paneleiras. Antes da construção do primeiro Galpão, o que ocorreu no final da década de 1980, os processos de produção e de comercialização das peças cerâmicas ocorriam no próprio ambiente residencial das Paneleiras. $\mathrm{O}$ ritmo da produção, em grande medida, seguia o ritmo dos afazeres domésticos, e a relação com os clientes ocorria de forma mais intimista e de maior fidelidade. Naquele contexto pré-Galpão, os quintais, como bem observa Simão (2008:168), possuíam uma função no sistema local que extrapolava a ideia de "local de trabalho". Os quintais eram, antes de mais nada, "lugares de produção de sociabilidade, de extensão e de ajuda mútua, que muito contribui para a compreensão das relações sociais de produção dessa localidade”.

Todavia, com as modificações em curso desde os anos 1950-60, aos poucos os quintais foram pressionados pelo avanço imobiliário. Além disso, à medida que os núcleos familiares das Paneleiras aumentavam, exigindo a construção de novas residências e/ou de "puxadinhos", os quintais eram reduzidos. Paralelamente a esse processo, verificou-se a partir de finais dos anos 1980 um aumento da demanda por panelas de barro impulsionado pelo crescimento do fluxo de consumidores diretos e de turista na região de Goiabeiras (Dias, 2006; Nicole et. al. 2012). Assim, as Paneleiras, ainda nos quintais, se viram diante da dificuldade de ampliarem sua produção frente ao aumento da demanda. Não demoraria muito para essa realidade, atrelada, como veremos na próxima seção, ao conflito que as Paneleiras passaram a travar com o Governo do Estado e a ação de atores externos, fomentasse a criação da Associação, o que ocorreu em 1987, e a reivindicação de um local coletivo para a produção, estocagem e comercialização de panela de barro, fato levado a cabo no ano seguinte à construção da APG (Perota et. al, 1997; Dias, 2006; Simão, 2008). 
Embora o deslocamento das Paneleiras para o Galpão tenha sido um processo de mudança gradual, até hoje tem impactado diretamente a organização produtiva e social das Paneleiras. Como destacam Dias (2006), Simão (2008) e Camiletti (2012), trabalhar no Galpão representou uma nova realidade; passou a significar uma transformação de um ofício exercido secularmente em ambiente familiar, que seguia o tempo dos afazeres domésticos, o cuidado dos filhos, a "entreajuda", para uma realidade com dimensão institucional, marcado por questões administrativas que antes não faziam parte da realidade da maioria dos sujeitos. Marcou, também, o surgimento de novas relações comerciais e políticas.

Com relação à dimensão comercial, as Paneleiras se viram diante de novas dinâmicas tanto com relação aos consumidores quanto às próprias Paneleiras: os consumidores, até então quase sempre clientes fixos que frequentavam as casas das Paneleiras, passaram a se direcionar para o Galpão, dando início a uma nova realidade concorrencial faca-a-face entre as Paneleiras não estamos a argumentar que a concorrência não existisse, mas, certamente, não se processava nos mesmos moldes ${ }^{14}$. Já a dimensão política se refere tanto às relações entre os associados e os poderes públicos locais, que passaram a desenvolver ações junto à APG, sempre limitadas ao ambiente do Galpão, e entre os próprios associados, que passaram a conviver com uma dimensão mais estrutural entre Paneleiras da Diretoria da APG e Paneleiras associadas.

Além disso, a construção do Galpão fomentou um processo de distinção entre o grupo social. Devido às condições precárias da instalação do primeiro Galpão ou pelo fato de muitas Paneleiras não se adaptarem à nova estrutura produtiva e comercial das panelas de barro no novo ambiente, algumas mantiveram a produção no ambiente doméstico, mesmo carecendo de espaço para produzir, estocar e vender as peças. Ao longo do tempo, surgiu o termo "Paneleira do Galpão" e "Paneleiras de Fundo de Quintal" - durante nossas investidas em campo, percebemos que o termo "fundo de quintal" não é benquisto pelas Paneleiras que mantêm a produção no espaço residencial; devido a essa constatação passamos a utilizar o termo "Paneleiras de Quintais"15.

Como buscaremos sustentar na próxima seção, essa "fragmentação interna" ao grupo social tem sido um grande promotor para o grau geral de "insatisfação/desconfiança institucional" e de "baixo associativismo/envolvimento institucional". Outro fato que também não podemos perder de vista, e que buscaremos problematizar na sequência, ao remontarmos as

\footnotetext{
${ }^{14}$ A concorrência também fomentou pequenas inovações estéticas impressas nas panelas. Como destacam Nicole et. al. (2012:40), o diferencial "estético geralmente é manifestado na estilização de tampas e alças, feitas em formatos que fogem ao típico, como na inscrição de frases e na reprodução de peixes nas alças, por exemplo" - algumas imagens podem ser encontradas no referido trabalho e em Marques e Caloti (2013).

${ }^{15}$ Para uma leitura sobre a mudança dos sentidos do termo, ver Simão (2008) - a autora, entre um trabalho e outro, também identifica essa recusa pelo termo "fundo de quintal".
} 
relações políticas que se fizeram presentes no processo de construção da APG, é que, por um lado, se esse descolcamento dos quintais para o Galpão representou melhorais nas condições de trabalho - ao menos para quem atualmente trabalha no interior do Galpão -, bem como a possibilidade de fazer do ofício sua principal fonte de renda, o que pôde, inclusive, ter contribuido positivamente para o fortalecimento cultural, por outro, o sistema de entreajuda foi substituído por "terceirização" de determinadas etapas do processo produtivo ${ }^{16}$ : em outras palavras, aqueles laços de solidariedade e reciprocidade presentes nas relações de entreajuda foram reduzidos.

\section{Construção da APG: conflito, atores, instituições e a percepção dos sujeitos}

O contexto de construção da APG foi marcado por forte agitação política em torno dos novos caminhos da recém-democratização do país nos anos 1980. Cerca de um ano depois da criação da APG, o Brasil promulgaria sua "Constituição Cidadã”. A Constituição de 1988, marco definitivo da redemocratização, representou o fundamento legal das mudanças institucionais e um novo padrão de interações entre o Estado e uma sociedade civil permeada pela emergência de novos atores sociais no debate político (Dagnino, 2004; Gohn, 2005; Pinto, 2004).

No Espírito Santo, esse movimento de agitação social e política foi marcado por um cenário paradoxal. Por um lado, havia um processo de desenvolvimento e modernização e, por outro, configurava um cenário político tradicional, marcado por relações clientelísticas e paternalistas. Esse complexo cenário evidenciava um:

(...) descompasso entre mudanças nas esferas social e política, por um lado, e na esfera econômica, por outro. Ou seja, enquanto nesta verificava-se um processo de modernização acelerado que inseria a economia estadual nos circuitos internacionalizados, colocando-a no ranking daqueles estados da Federação com os maiores índices de crescimento, nos âmbitos político e institucional verificava-se um processo de involução, no que respeita aos padrões de relações público-privado (Domingues; Palassi; Gonçalves, 2011:3).

Corroborando Domingues, Palassi e Gonçalves (2011), entendemos que as consequências de tal cenário político na qualidade da democracia, seja no contexto dos anos 1980, seja no atual, podem ser muitas, como a criação e/ou manutenção de relações clientelísticas, personalismo político, baixa participação política e "relações perigosas" entre o público-privado. Tendo em

\footnotetext{
16 Além da figura principal dos atores detentores do saber-fazer, passou a existir, já na década de 1990, outras “funções", como o "tirador de barro", o "casqueiro" (pessoa paga para extrair a casa do mangue-vermelho utilizada para a produção da tintura usada no açoite das peças cerâmicas durante a queima), a "alisadeira" (pessoa paga para realizar apenas a etapa de "polimento" das peças) e o "preparador de barro" (pessoa paga para preparar o barro extraído do barreiro, misturando a argila e retirando as impurezas, como pequenas pedras e resto de vegetação).
} 
vista esse contexto político nacional e local e refletindo sobre o processo de construção da Associação das Paneleiras de Goiabeiras (APG), algumas indagações podem surgir: Será que a construção da APG ficou imune às relações políticas tradicionais locais? Será que o processo político de criação e consolidação da APG permitiu o desenvolvimento de práticas participativas dos sujeitos?

Pelo exposto até o momento, percebemos que havia em Goiabeiras uma fonte de capital social originárias das relações de entreajuda em um contexto de dificuldades e limitações. A indagação que fazemos, contudo, é se o processo de construção e consolidação da APG, considerando, igualmente, o contexto político local, foi mobilizado para uma forma de envolvimento institucional dos sujeitos junto à Associação. Sustentamos que não foi. Daí surge uma nova questão: como foi possível, então, criar a APG?

Concordamos com a literatura respeitante às Paneleiras que aponta dois fatos para a criação da APG: a) as mudanças pelas quais passou Goiabeiras a partir dos anos 1960, especificamente a redução do espaço dos quintais, o aumento da demanda pelas peças cerâmicas e a necessidade de um local coletivo de trabalho e b) o conflito com o Governo do Estado, representado pela Companhia Espírito-Santense de Saneamento (CESAN), a partir da década de 1980 (Perota et. al., 1997; Dias, 2006; Dossiê IPHAN 3, 2006; Simão, 2008; Marques, 2020). Estes são fatos que, indubitavelmente, potencializaram o processo de organização das artesãs. Contudo, sustentamos que ao não mobilizar suficientemente o capital social, houve um processo de desmobilização dos sujeitos.

O primeiro fato, acreditamos, já foi explorado na seção anterior. Resta-nos, portanto, o segundo, que será problematizado com um terceiro: c) a atuação política de "elementos externos" no processo de construção da APG - elemento que não deixa de estar presente na literatura, sobretudo em Perota et al. (1997) e Dias (2006). Esses elementos são a então vereadora Etta Fern Gonçalves de Assis, a Prefeitura Municipal de Vitória, representada na gestão de Vitor Buaiz (PT), e o IPHAN.

Como veremos, esses atores foram de grande importância no processo político que criou e consolidou a APG. Um processo, contudo, que não proporcionou uma maior participação dos sujeitos nos momentos de tomadas de decisão, limitando, dessa forma, o desenvolvimento de uma eficácia da participação (Pateman, 1992) que, ao longo do tempo, proporcionasse uma cultura política associativo-participativa entre os associados. Passemos ao nosso segundo fato social relacionado à criação da APG. 


\section{Conflito, atores e instituições: $O$ caso da CESAN (1988-2002) e a percepção dos sujeitos sobre a APG pós-2002}

A década de 1980 também marcou o segundo fato histórico determinante para a criação da Associação: o conflito entre as Paneleiras e o Governo do Estado, representado pela Companhia Espírito-Santense de Saneamento (CESAN), em torno do barreiro. O momento detonador foi o ano de 1988, quando o Governo do Estado decretou como utilidade pública e desapropriou a área do Vale do Mulembá ${ }^{17}$, para a construção de uma Estação de Tratamento de Esgoto (ETE) ${ }^{18}$. A partir daquele momento, os conflitos foram acirrados:

O Barreiro foi reivindicado como fonte "inesgotável" da matéria-prima que fundamenta o processo produtivo do grupo, de modo que sua preservação significava a continuidade da estrutura que as mulheres criaram para si. O Barreiro, como o lugar da matéria dessa tradição, é parte do território, assim como Goiabeiras. O Barreiro representava o local onde as mulheres buscavam a legitimação "ancestral" do seu fazer (...) já que extraem barro dali desde que começaram a fazer panelas. Lutavam pelo que acreditavam ser seu por direito, mas também pelo reconhecimento (Dias, 2006:94 [Grifo nosso]).

Reivindicado como fonte de matéria-prima e lugar de memória ${ }^{19}$, o barreiro provocou uma luta por sua manutenção, a qual foi fundamental para a organização política das artesãs enquanto grupo e para a articulação discursiva de invenção da tradição ${ }^{20}$. Como destaca Dias (2006:95), foi através da luta pelo barreiro e das alianças políticas que se traduziu "a constituição da Associação como um corpo coletivo, que passou a se constituir como categoria reconhecida, com uma identidade social e uma ação politicamente localizada no contexto cultural e social do Estado".

Não questionamos o fato de que a luta pelo barreiro tenha contribuído para articular as artesãs em torno de uma instituição que representasse seus interesses. Essa luta se deu contra um "adversário comum" para todos os sujeitos: o Governo do Estado do Espírito Santo, que, ao

\footnotetext{
${ }^{17}$ O Vale do Mulembá é uma região do bairro Joana D'Arc, bairro próximo a Goiabeiras. É nessa região que se localiza a fonte de matéria prima do ofício das Paneleiras, comumente denominada de "barreiro".

${ }^{18}$ Decreto $\mathrm{n}^{\circ} 3690$-E, de 25 de janeiro de 1988

${ }^{19}$ Como destaca Nora (1993), lugares de memória devem ser entendidos de forma ampla como lugares espaciais, lugares abstratos, lugares simbólicos, monumentos, festividades, datas, dentre outros, que passam a ser mobilizados na construção da memória. Os "lugares" só se tornam lugares de memória quando significados pelos sujeitos como pontos de identificação de um discurso. No discurso de tradição do saber-fazer panela de barro em Goiabeiras, diferentes lugares de memórias são evocados como estando diretamente relacionados ao desenvolvimento do ofício na região de Goiabeiras, tais como o barreiro, o manguezal, a Festa das Paneleiras e a própria APG (e o Galpão), sobretudo durante os anos 1980-1990.

${ }^{20}$ A ideia de "tradição inventada", termo cunhado por Hobsbawn (1984:09), designa um processo de construção coletiva de um sistema sígnico, respeitante ao passado e reproduzido no presente. Como destaca o autor: "Por "tradição inventada" entende-se um conjunto de práticas, normalmente reguladas por regras tácitas ou abertamente aceitas; tais práticas, de natureza ritual ou simbólica, visam inculcar certos valores e normas de comportamento através da repetição, o que implica, automaticamente; uma continuidade em relação ao passado. Aliás, sempre que possível, tenta-se estabelecer continuidade com um passado histórico apropriado". Cf. Marques (2019).
} 
colocar em risco a principal matéria-prima, colocava igualmente em risco a manutenção do saber-fazer dos sujeitos e, portanto, sua identidade. Essa inter-relação conflitiva fomentou a construção discursiva da identidade coletiva enquanto "Paneleiras de Goiabeiras": havia um "ele" (Governo do Estado = CESAN) e um "nós" (Paneleiras do Galpão e Paneleiras de Quintais) na produção de um processo de identificação político-social; os sujeitos passaram a se identificar como "Paneleiras de Goiabeiras"21.

Esse conflito só foi definitivamente resolvido no ano de 2002, momento em que o Governo do Estado e a Diretoria da APG assinaram um acordo permitindo a construção da ETE no local $^{22}$. Desde então, tem se sobressaído um discurso de cooperação entre a APG e as instituições estatais - a existência de um padrão de inter-relação cooperativa entre as Paneleiras e o Estado, vale destacar, não significa que não existam interações conflitivas. Os conflitos são constantes em torno da organização e realização da festa anual das Paneleiras, bem como sobre a necessidade de ações de visibilidade turística e no apoio na manutenção da estrutura do Galpão.

Após o fim das interações conflitivas com o Estado, momento em que houve um tipo especial de envolvimento político-identitário das Paneleiras com a APG, o que se destaca cerca de duas décadas depois é uma identificação das Paneleiras com a APG diretamente relacionada à ideia de "lugar de trabalho", sobretudo com relação às Paneleiras do Galpão. Ou seja, a identificação dos sujeitos com a APG como um elemento de organização política, perdeu forma com o tempo.

Não é difícil perceber os indícios nas narrativas dos sujeitos que correlacionam a APG ao Galpão (espaço físico), destacando este como "nosso local de trabalho", “dependemos do Galpão para trabalhar e sobreviver", "é o nosso ganha pão", dentre outros. Isso é mais claro quando buscamos verificar a percepção sobre a "avaliação" APG. A percepção é quase sempre "negativa", a não ser quando o inquerido fez ou ainda faz parte da Diretoria da $\mathrm{APG}^{23}$ :

Olha, satisfeita eu estou [com a APG], porque meu ganho vem daqui da Associação das Paneleiras; meu trabalho é esse, eu sou sozinha mesmo, meu custo sai tudo daqui (...) Ah eu dou [nota] nove. Porque se não fosse a Diretoria, a Associação tinha fundado (Já fez ou faz parte da Diretoria).

\footnotetext{
${ }^{21}$ Além dessa relação com a CESAN, o processo de identificação como Paneleiras de Goiabeiras também envolve outra relação conflitiva: a relação com os artesãos de Guarapari. Devido ao escopo da presente proposta de discussão e aos limites comuns a um artigo, que já mostra extenso, deixaremos essa discussão para uma oportunidade futura.

${ }^{22} \mathrm{O}$ momento e as consequências desse acordo podem ser conferidos em Abreu (2005) e Simão (2008).

${ }^{23}$ Devido à tensão nas relações entre Paneleiras de Quintais e Paneleiras do Galpão no momento em que escrevemos esse artigo, quando o IPHAN estava a realizar a pesquisa de Revalidação do Ofício das Paneleiras de Goiabeira, e a fácil identificação dos entrevistados por qualquer Paneleira, optamos pela ocultação das iniciais dos nomes dos entrevistados.
} 
A Associação ela traz benefícios desde o momento que nós já temos o barro, já temos o seu lugar de... Já pensou se eu fosse pagar uma lojinha pra botar minha mercadoria? Então já ajuda bastante [a APG] (...). Bom, do jeito que ele tá bonito hoje eu acho que eu daria dez (...) o galpão tá bom meu filho. Agora nós estamos no mar de flor, não é no mar de rosa não, tá pra chegar a rosa (risos). A gente já trabalhou na lama! (Já fez ou faz parte da Diretoria).

Olha só... A renda hoje, pra antigamente, como não tinha associação, é... Era em casa, em casa, certo? (...). O que que acontecia... Os compradores chegavam e pechinchavam o máximo possível. Hoje, botou a margem de preço, que ele vem passando e todo... É praticamente um real, dois reais, três reais que vai mudar de uma banca pra outra... Isso aí influencia bastante você pegar lá, e antigamente... Associação era pouco divulgado, também as Paneleiras (...). Pra associação daria um sete, porque na verdade deveria ser uma cooperativa (Não fez ou não faz parte da Diretoria).

O benefício que traz é isso aí que falei com você [local de trabalho - Galpão]. Se nós pagar a associação aí vem sacola, vêm receitas, senão nós não temos (...). Ah, eu dou cinco! Nota cinco (Não fez ou não faz parte da Diretoria).

Benefício, benefício... Bom... nós temos o espaço para trabalhar, né [Galpão]... Então trabalhamos aqui porque existe uma Associação. Mas dizer que eu concordo com a maioria das coisas que uma Diretoria faz, eu não concordo (...). Para Associação? Eu daria uma nota quatro (Já fez ou faz parte da Diretoria).

A importância é o Galpão, né? Para os associados? Acho que praticamente quase não ajuda, porque... o quê se fala numa reunião não é colocado em prática, e a gente tenta resolver numa reunião e... diz que vai resolver, e não é colocado em prática (...). De zero a dez? Eu daria só quatro, só quatro (Não fez ou não faz parte da Diretoria).

O benefício que traz para nós é a gente ter um local para trabalhar (...). É ter um local para trabalhar, saber que aquilo ali eu tô cooperando com aquilo ali, para aquilo ali crescer. Eu tenho um local aqui dentro porque eu pago pra eu ter um lugar aqui dentro (...). Enquanto associada eu não tenho satisfação não (...). [dou] nota quatro (Já fez ou faz parte da Diretoria).

Com relação à "avaliação" da APG por parte das Paneleiras que trabalham nos quintais, o resultado é ainda mais expressivo:

Nada, não traz nada. Nós somos associadas, pagamos nossas mensalidades (...). Somos associadas pra ganhar nada (...). Nota? Zero! (...). Lá na associação, eles trabalham... Ali é que é o ponto turístico, é o que é mais divulgado (...) as Paneleiras era bem melhor sem Associação, sem nada, para mim (Não fez ou não faz parte da Diretoria).

Nunca tive [satisfeita com a APG]. É por causa que não é bem uma Associação. Porque eles não comunicam com a gente pra gente ser unido em tudo (...). [dou] nota zero (Não fez ou não faz parte da Diretoria).

Para nós? Assim, quando tem algum evento [exposição em outro estado] eles avisam. Agora, viagem, eles vão viajar... então é só mais gente de lá (...). do Galpão. Fica tudo lá. Nota? No geral seis (Já fez ou faz parte da Diretoria).

Acreditamos que a percepção que os sujeitos têm da APG, raramente alusiva à ideia de envolvimento institucional associativo-participativo ou como espaço de organização política, tenha impactos na relação de confiança institucional dos sujeitos com relação à instituição, o que 
dificulta o fortalecimento da própria APG como entidade político-representativo do grupo, o que foi forte nos anos 1980.

Isso ajuda a compreender, por exemplo, os argumentos de Brandão (2014) sobre as ações estratégicas do SEBRAE para promoção do selo de Indicação Geográfica (IG) das panelas de barro. Como destaca a autora, durante as incursões do SEBRAE, percebeu-se que a Cultura Organizacional das Paneleiras de Goiabeiras não permitiu grandes sucessos nos esforços para o desenvolvimento de ações administrativas por parte de instituições parceiras, como o IPHAN e o próprio SEBRAE. Ainda segundo Brandão (2014:101), a Cultura Organizacional das Paneleiras "foi um empecilho no processo devido à dificuldade do grupo de trabalhar de forma colaborativa". Essa questão fica ainda mais clara com o depoimento de um agente do SEBRAE à Brandão, ao afirmar que, ao chegarem a Goiabeiras, encontraram "um grupo totalmente esfacelado, que já se tinha tentado trabalhar cooperativismo, associativismo, métodos de produção mais limpa e sedimentada e nada tinha funcionado" (2014:99).

Também percebemos essas dificuldades apontadas por Brandão (2014) nas entrevistas realizadas com gestores da Prefeitura Municipal de Vitória e com técnicos do IPHAN. Como destacou P. B., Gerente de Patrimônio Histórico Cultural da Prefeitura Municipal de Vitória, as dificuldades financeiras da APG têm sido um fator complicador na autonomia da Associação face às instituições estatais ${ }^{24}$ : “o que impacta mesmo é que a Associação não é suficientemente organizada, infelizmente, para conseguir ter um caixa decente (...), então eles não se mantêm"25. Já F. R. C., Subsecretário da então Secretaria de Turismo, Trabalho e Renda (SEMTTRE), também foi incisivo quanto à necessidade de atuar no sentido de buscar um fortalecimento institucional da APG: "a gente sempre tem trabalhado muito numa dimensão do fortalecimento institucional delas, que é a parte de como esse associativismo pode ser efetivo. Hoje, a gente enxerga que elas são uma associação que não atua como associação" ${ }^{\text {26 }}$.

O que temos sustentado, e buscaremos aprofundar na próxima seção, é que essas questões, as quais estão relacionadas ao que temos destacado como "desconfiança institucional" e "baixo associativismo/envolvimento" em relação à associação, se devem ao fato de que o processo de construção da APG não mobilizou suficientemente o capital social presente nas relações sociais dos sujeitos para uma forma de envolvimento institucional-participativo junto à APG. O que problematizaremos, a seguir, é o papel desempenhado pelos "elementos externos"

\footnotetext{
${ }^{24}$ Autonomia entendida como autonomia econômica (fonte própria de recursos da APG).

${ }^{25}$ Entrevista cedida aos 19 de agosto de 2016.

${ }^{26}$ Entrevista cedida aos 19 de agosto de 2016.
} 
no contexto de criação e consolidação da APG. A atuação desses elementos também não tem contribuído para a criação de práticas político-administrativas participativas.

\section{Ações "externas": atores e instituições}

As ações de representantes do poder público local foram significativas para a criação da APG. Referimo-nos especialmente ao papel desempenhado por Etta de Assis, então vereadora, à ação da Secretaria Municipal de Ação Social da Prefeitura de Vitória, durante a gestão de Vitor Buaiz (PT), entre 1988 a 1992, e à atuação do IPHAN, tanto durante conflito com a CESAN quanto nos estudos que resultaram no Registro do Ofício das Paneleiras de Goiabeiras como patrimônio imaterial.

O primeiro relato das ações de Etta junto à APG é apresentado por Perota et. al. (1997). Segundo os autores, a vereadora teve papel fundamental no processo de construção da Associação, inclusive, o primeiro estatuto foi elaborado pela então vereadora. A mesma informação é encontrada em Dias (2006):

Seu estatuto foi elaborado pela vereadora Etta de Assis, do PMDB, que presidiu a assembleia de fundação, no governo de Albuíno Azeredo. Segundo documento do governo do Estado de 1993 sobre o "complexo das Paneleiras", a criação da Associação surgiu do interesse da vereadora, que pensava "ser essa uma das formas de as Paneleiras adquirirem recursos, além de criar uma entidade que representasse o interesse das artesãs" (Dias, 2006:91).

Pela citação, percebemos que a influência de Etta de Assis foi mais do que uma assessoria no processo de organização das artesãs e na criação do primeiro estatuto da Associação; sua atuação foi mais profunda, determinante, verticalizada e paternalista. Foi Etta de Assis quem também indicou a primeira Presidente da Associação, Dona Melchiadia:

(...) mediante ação externa e pessoal, [a vereadora] nomeou também a presidente, sem eleições ou qualquer tipo de participação das Paneleiras, mesmo porque neste momento as mulheres ainda não constituíam um grupo de identidade e trabalhavam isoladas em suas casas ou como empregadas no Galpão de Arnaldo Gomes ou no quintal de Melchiadia (Dias, 2006:38).

A entrevista cedida por Melchiadia à Dias (2006), em 1997, é ainda mais esclarecedora:

A Associação foi assim: tinha uma mulher aí, da secretaria, que há muito tempo tinha vontade de fazer a Associação, mas o pessoal nunca se entrosava. Um dia chegou uma mulher que ia ser vereadora, deputada, não sei, ela inventou de fazer a Associação e fez. Ela foi lá, fizemos uma reunião, tinha umas quatro, cinco Paneleiras, vamos botar em votação, quem vai ficar para presidente, aí ficou a mim, aí a gente continuou (...). Agora, de uns tempos para cá, que mudou muito. Aí inventamos uma festa. Depois eu entreguei à Marinete, teve votação, votaram para ela, ela ficou. Viajar a gente viaja, a Secretaria viajava com as panelas nossas (Dias, 2006:92). 
Cumpre destacar que as pesquisas de Dias datam da década de 1990. Melchiadia, já falecida, foi uma personagem fundamental no processo de criação e estruturação da APG, inclusive, ainda hoje é reconhecida entre as Paneleiras como liderança fundamental naquele processo; era ela quem tinha relação mais direta com Etta de Assis. Em nossas abordagens recentes com o grupo de artesãs, a figura da ex-vereadora pouco veio à tona, com exceção de algumas Paneleiras que eram mais próximas de Melchiadia durante o processo de criação da APG, e mesmo assim só surgiu a partir de perguntas objetivas sobre quem foi Etta de Assis.

A figura que emergiu com facilidade nas narrativas dos sujeitos foi a da assistente social da Prefeitura Municipal de Vitória (PMV), J. F. Em entrevista, J. F., assim como o ex-prefeito Vitor Buaiz, narrou que a aproximação da Prefeitura com as Paneleiras, mais especificamente a Secretaria Municipal de Ação Social, ocorreu a partir de um projeto mais amplo da gestão municipal de registro e acompanhamento de setores informais da capital. Ainda segundo a assistente social, naquele momento a municipalidade já tinha clara a importância do papel das Paneleiras na cultura da cidade, mas, até então, faltava um plano de ação para trabalhar com as Paneleiras e com APG. Como destacou, sua ação junto às Paneleiras ocorreu no sentido de fortalecer o grupo enquanto associação, a partir do empoderamento dos sujeitos em relação à sua situação política e econômica e sobre a representatividade cultural para a cidade de Vitória.

Além disso, a gestão local, como destacou Vitor Buaiz, também estava ciente do conflito com a CESAN e atuou de forma objetiva no sentido de apoiar as artesãs junto às instâncias jurídicas contra as pretensões da CESAN. Como narrou:

\begin{abstract}
Tinha que preservar aquele mangue ali da ilha de Vitória, um dos maiores do país (...) e garantir que aquilo continuasse sendo uma tradição da cultura capixaba e pudesse chegar aonde chegou hoje (...). Também teve a discussão com a CESAN, porque o barreiro era o único que havia aqui na cidade de Vitória, e a CESAN queria construir uma estação de tratamento de esgoto... Então a Prefeitura comprou a briga, comprou a briga porque não tinha como você deixar que elas perdessem (...), isso é uma cultura que veio de pais, mães para filhas, isso para nós foi muito determinante para que a gente decidisse a posição de que lado nós estávamos (Vitor Buaiz, ex-Prefeito de Vitória. Entrevista cedida aos 12 de agosto de 2016 [Grifos nossos]).
\end{abstract}

Mais do que um importante papel no processo de consolidação da APG, a gestão municipal, como bem observou Dias (2006), atuou no processo de sedimentação da "invenção da tradição" das Paneleiras:

A equipe da Prefeitura foi fundamental para a formação da identidade das Paneleiras, que se percebiam como empregadas, mas que a partir de então criaram uma identidade para o grupo, estabelecendo a categoria socioprofissional e cultural pela qual desejaram ser reconhecidas. Este apoio possibilitou às mulheres o acesso a mecanismos institucionais até então inalcançáveis. Assim, as políticas públicas petistas criaram condições para definir uma identidade de Paneleira, já que antes elas eram artesãs, mas 
não Paneleiras. Surge então um novo padrão histórico de interação intragrupo (Dias, 2006:93)

As ações da municipalidade de Vitória, portanto, não se limitaram ao processo de consolidação da APG. Havia, outrossim, o anseio de fomentar uma política cultural que, de alguma forma, também divulgasse o turismo local. Como parte da divulgação, em 1990, com apoio da Prefeitura, foi organizada a primeira Festa das Paneleiras ${ }^{27}$.

Remontar esse contexto vinte e cinco anos depois, por meio de entrevistas, não é algo fácil para nós, analistas, pois, obviamente, os sujeitos estão cientes do processo histórico e constroem as suas próprias narrativas. Analisando retrospectivamente, tanto J. F. como Vitor Buaiz sustentam que as ações da Prefeitura, ao contrário do que fez Etta de Assis, foram estruturadas no sentido de auxiliar as Paneleiras em seus processos decisórios e não de ações verticalizadas. Dias (2006), que também analisou as ações da Prefeitura ao longo dos anos 19801990, também argumenta que as ações da municipalidade foram realizadas a partir de uma perspectiva colaborativa. Não estamos, com isso, colocando em questão o "real" apoio ou as "reais intencionalidades" da Prefeitura em concentrar seus esforços em uma proposta de autoorganização da APG. O que questionamos é se as ações de fato proporcionaram, ou fomentaram, o envolvimento dos atores sociais mobilizando o capital social do grupo à época da criação e organização da APG, ou se limitaram a uma perspectiva restrita de participação, isto é, um envolvimento participativo que não alcança os espaços e momentos de decisão políticoadministrativo.

Com relação à atuação de Etta de Assis junto à $\mathrm{APG}$, não temos dúvidas de ter se tratado de uma ação verticalizada e paternalista que não considerou as relações de reciprocidade e solidariedade existentes entre os sujeitos. Ao invés de buscar um envolvimento coletivo dos sujeitos, já habituados a cooperarem entre si, mesmo que em relações sociais comunitárias e não associativas, a então vereadora iniciou o processo de forma direta e, desde o início, o personalizou (em Dona Melchiadia e, de certa forma, em si mesma). O mesmo não pode ser afirmado categoricamente com relação à Prefeitura. Todavia, isso não significa que a Prefeitura não tenha atuado diretamente e, em grande medida, de forma diretiva, sobretudo no sentido da sedimentação do discurso de "tradição" das Paneleiras perante o grave contexto de conflito com a CESAN. Afinal, havia um risco real para as Paneleiras de perda de acesso à principal matéria-

\footnotetext{
${ }^{27}$ A Festa das Paneleiras, já com mais de vinte edições, também representa o Dia das Paneleiras - que passou a ser comemorado oficialmente a partir do dia 02 de junho de 1993 pela Lei municipal $n^{\circ}$ 3.944, de Julho de 1993. A organização ocorre em parceria entre a Associação e a Prefeitura Municipal de Vitória. As últimas edições também contaram com parcerias decisivas do setor privado.
} 
prima e, como vimos na narrativa de Vitor Buaiz, estava claro para a Prefeitura o seu lado nesse conflito.

Outra instituição importante nesse processo foi o IPHAN. A atuação mais direta da instituição junto às Paneleiras ocorreu a partir da segunda metade dos 1990, com a pesquisa que resultou no Registro do Ofício das Paneleiras como Patrimônio Cultural Imaterial do Brasil, no ano de 2002. Assim como podemos argumentar que Etta de Assis e a Prefeitura tinham “demandas particulares" ao ingressarem na articulação com as Paneleiras - Etta por interesses políticos, a Prefeitura com seu programa relacionado ao setor informal e no desenvolvimento de políticas culturais e turísticas -, o IPHAN também apresentava suas demandas, afinal, as discussões internas sobre políticas culturais de natureza imaterial estavam em plena efervescência no Brasil e logo seria necessário inaugurá-las.

Como destaca Abreu (2005), o reconhecimento do modo de fazer panelas de barro das Paneleiras de Goiabeiras era uma demanda antiga, inclusive do próprio IPHAN, mas só foi possível levar a cabo com a criação do Inventário Nacional de Referências Culturais (INRC), que aconteceu entre 2001 e 2002. Em entrevista com T. C. A, então Diretora da $6^{\text {a }}$ Sub-regional do IPHAN no Espírito Santo à época do Registro, percebemos que a iniciativa e o interesse de patrimonializar o saber-fazer panelas de barro de Goiabeiras partiu de agentes externos às Paneleiras. Questionada se foram os sujeitos que procuraram o IPHAN para solicitar o estudo que resultaria no Registro, T. C. A foi clara: “O IPHAN até então tratava dos edifícios históricos, do patrimônio material. Eu fui lá, e falei pra elas [Paneleiras] sobre a possibilidade de reconhecimento e valorização do ofício delas como patrimônio nacional (...) [as Paneleiras] não tinham procurado o IPHAN (...)" (Entrevista cedida aos 25 de agosto de 2016). A indagação se repetiu uma vez mais: “A associação já existia há quase dez anos, e não procurou o IPHAN antes?":

Já existia, exatamente... Não, não procurou, porque, olha só, não existia essa política no IPHAN, a política do patrimônio imaterial ela só veio a existir, de fato, como tal, a partir do decreto presidencial de 2000, mas mesmo assim o primeiro Registro se deu em 2002 (...). O IPHAN não era procurado, não era mesmo, comecei a trabalhar no IPHAN [Sub-regional do Espírito Santo] em noventa, e aí o foco era no patrimônio arquitetônico, porque estava tudo caído, estava tudo péssimo. Então minha primeira missão aqui foi, vendo o quadro que estava, recuperar o que era a vitrine do IPHAN, que era a cara do IPHAN, e o que era o IPHAN? O IPHAN é o Instituto do Patrimônio Histórico e Artístico Nacional, com meia dúzia de monumentos tombados e tudo caindo (...) já bem no final de 2000 fui lá e falei com a Diretoria [da APG] (...). Então eu fui e me apresentei e disse: "olha, o IPHAN tem essa nova linha, vocês já são o ícone mais importante da identidade cultural do Espírito Santo... principalmente de Vitória, mas também do Espírito Santo, porque a panela de barro é capixaba, no final de tudo, a moqueca capixaba está vinculada ao seu ofício... então o Registro pode dar uma visibilidade, uma força maior pra vocês" (T. C. A. Entrevista cedida aos 25 de agosto de 2016) 
Se considerarmos, como bem salientou T. C. A, que a política voltada para o Patrimônio Cultural Imaterial, entre finais da década de 1990 e início dos anos 2000, era uma experiência ainda incipiente, inclusive para o IPHAN, tanto que o Registro como Patrimônio Cultural Imaterial do saber-fazer das Paneleiras foi o primeiro bem registrado no Brasil, não é de se estranhar que as Paneleiras, ou qualquer outra instituição ou sujeito, não tenha procurado o IPHAN para dar início às consultas para iniciar a pesquisa de Registro do ofício, como determina a legislação. O fato é que o IPHAN também teve papel decisivo nesse processo e, assim como as demais instituições, atuou direta e verticalmente junto aos sujeitos.

Ações diretas e consideravelmente diretivas de instituições sobre as Paneleiras e a APG não se limitam ao contexto dos anos 1980 e 1990. A partir do reconhecimento de que a APG ainda hoje carece de maior envolvimento associativo dos sujeitos, instituições como a Prefeitura e o SEBRAE têm desenvolvido ações junto à Associação. O problema, contudo, é a forma como essas instituições buscam "resolver o problema": quase sempre de forma verticalizada, com pouca ou nenhuma mobilização dos sujeitos no sentido de proporcionar um sentimento de eficácia da participação nos termos de Pateman (1992). Um exemplo claro disso é a forma como a então Secretaria de Turismo, Trabalho e Renda do município de Vitória (SEMTTRE) pretendia reverter esse quadro:

A gente tem ações em andamento focado na melhoria do segundo andar [do Galpão da APG]. A gente quer transformar numa área bistrô e venda de souvenirs para as Paneleiras (...) aí que conflui sempre com o fortalecimento institucional; para elas começarem a ter mais independência sem precisar de dinheiro dos outros, porque elas sempre pedem ajuda, mas elas têm um produto que tem potencial econômico muito grande. Pelo fato delas deterem um patrimônio reconhecido nacionalmente, elas podem dar mais valor a esse produto e esse produto ajudar a manter a estrutura delas, elas não precisam ser tão dependentes da Prefeitura ou de outros órgãos públicos (...) então a nossa perspectiva ... a gente vem há dois anos dialogando com empresários que tenham interesse em explorar economicamente o segundo andar do galpão em parceria com elas. Agora também conseguimos com o Shopping Vitória uma loja pra poder vender as panelas de barro para aí conseguirmos o "instituto panela de barro", pra fazer esse gerenciamento, e que vai também fortalecer essa questão do associativismo delas, porque as panelas vão ser encomendadas, vão ser organizadas... é delas, o produto é delas sendo vendido no Shopping [entrevistador: "Mas dentro da loja vai ter gente da Associação?]: Não... elas vão ser as fornecedoras, a loja será gerida por outro pessoal, porque a gente tem o entendimento claro de que... o perfil delas... não têm o perfil de gestão administrativa. O papel de uma Paneleira e fazer panela mesmo, transmitir o conhecimento, tem que ficar focada naquilo ali, não que [haja] impeditivo para que elas façam o gerenciamento, mas a gente já tem várias experiências que não pode tirar elas da função originária delas; elas têm que ter um olhar sim pro associativismo, pra gestão, pro gerenciamento das coisas, mas sem sair da função principal delas. Então, por isso que a gente em todo trabalho (...) a gente não erra nisso mais, que é uma experiência que o passado já mostrou que elas não têm essa capacidade gerencial (...) (F. R. C. Entrevista cedida aos 19 de agosto de 2016). 
E as ações não se limitam a isso. A SEMTTRE pretendia desenvolver uma gestão administrativa externa para a APG com a instituição do que o Subsecretário intitulou como "Instituto Panela de Barro":

(...) com a abertura dessa loja no Shopping, que é o "instituto panela de barro", uma instituição sem fins lucrativos formada por gastrônomos - não é em prol das Paneleiras, as Paneleiras é um símbolo que eles usarão, mas é um instituto de gastronomia, de mestres culinários. Com a abertura dessa loja no Shopping, a gente pensa em criar um telefone concorrente [ao telefone público que existe no Galpão, usado contato formal da AGP], mudar todos os telefones que estão pela prefeitura, pelo IPHAN, tudo que divulga telefone parar de divulgar o orelhão e criar uma concorrência institucional. Só que as encomendas passariam pela Associação monitoradas pela prefeitura e pelo IPHAN... o quê vai acontecer? As encomendas... a gente vai passar a estipular enquanto negócio: "oh você tem uma panela de barro, qual é o preço da sua panela? qual o percentual dessa encomenda que vai ficar para a Associação? Para as ações de associativismo? Para a manutenção do espaço, para a limpeza, par a implantação do sistema de segurança?" (...). Então a gente começa a fazer essas ações no sentido de fortalecer, e as encomendas feitas na loja a gente pensa em fortalecer a divisão com as meninas que estão nas unidades produtivas [Paneleiras de Quintais] que acabam vendendo menos, que são as [Paneleiras] de residência, então existe um todo um conjunto de ações; sempre se está tentando prever esses mecanismos de fortalecimento institucional e associativismo delas (F. R. C. Entrevista cedida aos 19 de agosto de 2016).

Ações como as pretendidas pela SEMTTRE também estão presentes no SEBRAE. Como destaca Brandão (2014:74), os estudos do SEBRAE, que visavam a promover a sustentabilidade da APG, não fomentaram uma efetiva participação das Paneleiras nos espaços e momentos de decisão político-administrativa: "o Sebrae elaborou estudos e documentos com o objetivo de promover a sustentabilidade da APG, porém as Paneleiras não participaram da elaboração do plano de ação". Além de buscar promover a sustentabilidade local, mas sem a participação dos próprios sujeitos, as ações do SEBRAE buscam "profissionalizar a gestão com indicadores claros de agregação de valor econômico" (Brandão, 2014:87), algo que também parecia ser uma preocupação da SEMTTRE. Ao pensarmos em termos de ações voltadas para uma efetiva participação dos sujeitos nos processos de decisão que os afetam diretamente, como forma de tentar reverter os indicativos de "desconfiança institucional" e "baixo associativismo/envolvimento" em relação à Associação, inevitavelmente percebemos os limites dessas ações, pois não fomentam a participação do "público alvo". Os limites ficam ainda mais claros quando o próprio SEBRAE entende que:

(...) protegendo este grupo, dando reconhecimento e notoriedade a este produto [panelas de barro], você de uma certa forma, acaba organizando, tanto o processo de governança quanto o processo produtivo e a cooperativa que está envolvida por traz disso (...). Outro agente afirmou que "não dá para os próprios produtores fazerem daquilo, tocar aquilo, no dia-a-dia, uma associação ali caseira, isso não dá”. Ainda ressaltou uma necessidade "a gente tem que ter, por exemplo, em uma entidade gestora de IG [Indicação Geográfica] um secretário executivo, uma pessoa que responda 
profissionalmente, que seja uma pessoa de mercado e que esteja à frente disso" (Brandão, 2014:103 [Grifos nossos]).

Ao pensarmos no maior envolvimento participativo dos sujeitos, permitindo a geração de eficácia da participação como uma possível forma de potencializar a geração de maior confiança institucional, entendemos que sem ações que envolvam a participação direta dos atores e uma visão da necessidade de resgatar o capital social local, promovendo e fomentando as práticas colaborativas, os laços de confiança mútua, a horizontalidade nos processos políticoadministrativos, as ações estarão fadadas ao fracasso do ponto de vista participativo, associativo e de autonomia e sustentabilidade diante das instituições estatais.

Diante desse quadro de ações com pouca eficiência, eficácia e efetividade social ${ }^{28}$ do ponto de vista do associativismo e do fortalecimento institucional, não é difícil perceber os porquês de uma identificação dos sujeitos com relação à APG restrita à ideia do Galpão e, por conseguinte, às questões do trabalho, mais especificamente, como garantia do local de trabalho. Não percebemos um envolvimento institucional associativo e participativo e, como temos sustentado, esse quadro se explica, em grande parte, pela natureza das interações políticas no processo de construção e estruturação da APG, que não mobilizou suficientemente o capital social do grupo e que também não proporcionou práticas político-institucionais que pudessem fomentar uma cultura política associativo-participativa.

\section{Considerações finais}

O que percebemos ao longo do estudo foram ações que, umas mais outras menos, acabaram limitando a participação dos sujeitos nos processos de decisão e, com isso, pouco contribuíram para a mobilização dos associados em torno de práticas horizontalizadas e em uma cultura política participativa fomentada a partir do capital social do grupo. Mesmo que problematizássemos que não havia uma cultura política participativa e uma fonte de capital social impulsionando a criação da APG, ou que o processo de criação da mesma, dirigido por Etta de Assis e pela atuação da Secretaria de Ação Social da Prefeitura Municipal de Vitória, não

\footnotetext{
${ }^{28}$ Eficiência, eficácia e efetividade são três importantes elementos de uma avaliação de políticas públicas. A eficiência refere-se ao processo, à relação entre custo e benefício de uma ação realizada, visando ao melhor aproveitamento dos recursos (menor recurso, maior resultado). A eficácia, por sua vez, refere-se aos resultados efetivamente alcançados (metas atingidas) - está relacionada ao planejamento da política pública e sua real aplicação - o que não significa que se restringe à avaliação dos resultados parciais, mas sim, analisa o que fora planejado e o que foi realmente atingido, buscando sempre a maximização dos rendimentos das ações. Já a efetividade social diz respeito ao impacto da política pública na vida dos cidadãos; analisa as mudanças ocorridas na sociedade após sua efetivação, sempre avaliando os resultados econômicos e sociais da política pública (Borges; Marques, 2015)
} 
tenha proporcionado práticas associativas que ampliassem o capital social dos associados em geral, devemos considerar a influência mútua entre cultura política e estrutura institucional. Isso significa, como argumentamos na primeira seção deste estudo, que compreendemos que a relação entre cultura e estrutura políticas pode provocar mudanças na cultura política a ponto de gerar "confiança" a partir de seguidas experiências em práticas associativas e participativas na própria estrutura, o que poderia fomentar um processo de socialização assentado em uma cultura política participativa e, com isso, contribuiria com a emergência de capital social.

Contudo, como buscamos mostrar ao longo do trabalho, as pistas encontradas indicam baixo envolvimento associativo. O que consideramos indícios de aparente desinteresse e desmobilização dos associados, como a baixíssima presença destes em reuniões da Associação, e mesmo em reuniões promovidas pelo IPHAN durante a pesquisa de Revalidação do Ofício das Paneleiras de Goiabeiras ${ }^{29}$, e da correlação da Associação apenas enquanto "local de trabalho", podem ser causas explicativas para se refletir (e verificar e aprofundar por meio de surveys futuros) sobre a "(des)confiança” dos atores sociais em relação à Associação.

Pensando a partir dos prismas da cultura política, a falta de confiança e o baixo associativismo podem comprometer o fortalecimento e a autonomia política e administrativa da Associação e, consequentemente, em sua capacidade de mobilizar os associados em ações coletivas e na identificação política e administrativa dos associados em torno de si. No que se refere ao processo de significação dos sujeitos em geral à APG ("Paneleiras do Galpão" e "Paneleiras de Quintais"), não se percebe uma identificação política nos mesmos termos concebidos por Dias (2006), isto é, uma evidente identificação da APG como instituição representativa dos interesses políticos e econômicos dos associados, como a pesquisadora encontrou durante seus estudos entre finais de 1980 e início de 1990, momento de criação da APG.

No que diz respeito especificamente às Paneleiras de Quintais, a falta de "confiança" em relação à APG é ainda mais visível, pois há uma clara insatisfação dos sujeitos com o fato de não terem a mesma visibilidade "econômica" e política das Paneleiras do Galpão. Essa visibilidade, como os próprios sujeitos apontam, é, em parte, reflexo de anos de ações de instituições públicas direcionadas quase exclusivamente ao Galpão ${ }^{30}$.

\footnotetext{
${ }^{29}$ Em uma de nossas atividades de campo, realizada entre os meses de dezembro de 2015 a março de 2016 , foi possível acompanhar uma reunião pública do IPHAN com as Paneleiras. A reunião foi realizada na quadra da praça pública do bairro de Goiabeiras, no dia 23 de fevereiro, às 14:00. De um total de aproximadamente 70 Paneleiras atuantes em Goiabeiras, compareceram à reunião apenas 8. Destas, 5 eram "Paneleiras do Galpão" e 3 "Paneleiras de Quintais".

${ }^{30}$ Somente nos últimos anos esse problema foi percebido pelas instituições. O IPHAN, por exemplo, em sua recente pesquisa de Revalidação do Ofício das Paneleiras de Goiabeiras, tem buscado pensar em ações também com as
} 
Por fim, há que destacar que embora algumas Paneleiras de Quintais não queiram sair do ambiente residencial, sobretudo as mais idosas, a maior parte anseia por uma bancada no Galpão, pois tem consciência de que o esse local é a principal vitrine para comercialização de seus produtos. Além disso, ainda hoje o Galpão permanece sendo o principal foco das ações dos poderes públicos, sobretudo da Prefeitura Municipal de Vitória, do IPHAN e do Sebrae. Não é de se estranhar, portanto, a assimilação da Associação quase sempre restrita ao "lugar de trabalho" e não ao associativismo e à identificação política.

Acreditamos que os indícios são claros. O processo de construção da APG não mobilizou suficientemente o capital social existente nas relações sociais em Goiabeiras para uma forma de envolvimento junto à APG, acarretando, ao longo dos anos, uma baixa identificação políticoadministrativa dos associados em relação à mesma. Além disso, o processo político que consolidou a APG pouco contribuiu para o desenvolvimento de práticas participativas em seu interior, práticas que, a princípio, poderiam proporcionar maior envolvimento e identificação dos associados com a Associação. O resultado desse processo é uma percepção de “insatisfação/desconfiança institucional” e "baixo associativismo/envolvimento institucional”.

\section{Referências}

ABREU, Carol (2005), "Ofício de paneleira: conhecimento, reconhecimento e permanência", in A. Falcão, Registro e políticas de salvaguarda para as culturas populares. Rio de Janeiro, IPHAN, CNFCP, pp. 15-23.

ALMOND, Gabriel; SIDNEY, Verba (1970), La cultura cívica. Estudio sobre la participación política democrática en cinco naciones. Madrid, Fundación de Estudios Sociales y de Sociología Aplicada.

ASSOCIAÇÃO DAS PANELEIRAS DE GOIABEIRAS (19870, Estatuto da Associação das Paneleiras de Goiabeiras, Vitória.

BAQUERO, Marcello (2003), "Construindo uma outra sociedade: o capital social na estruturação de uma cultura política participativa no Brasil”. Rev. Sociol. Polít., Curitiba, n. 21, pp. 83-108 [Consult. 1011-2018]. Disponível em https://www.scielo.br/pdf/op/v14n2/05.pdf

BAQUERO, Marcello (2008), "Democracia formal, cultura política informal e capital social no Brasil". Opin. Pública, Campinas, v. 14, n. 2, pp. 380-413 [Consult. 10-11-2018]. Disponível em https://www.scielo.br/pdf/rsocp/n21/a07n21.pdf

BERGER, Mirela (s/d), A cultura como teia. [Consult. 07-09-2016]. Disponível em http://www.mirelaberger.com.br/mirela/download/a_cultura_como_teia.pdf

Paneleiras de Quintais, como a produção de material informativo e de sinalização no bairro para facilitar a localização das unidades produtivas das Paneleiras de Quintais. Contudo, mesmo que o IPHAN realize de fato essas e outras ações ainda mais estruturantes, os resultados só poderão ser analisados nos próximos anos. 
BORGES, Carlos N. F; MARQUES, Marcelo de S. (2015), "Intersetorialidade nas políticas públicas de esporte e lazer: uma análise do Programa Campeões de Futuro". Pol. \& Soc. v. 14, n. 29, pp. 93-123 [Consult. 10-12-2018]. Disponível em https://doi.org/10.5007/2175-7984.2015v14n29p93

BOURDIEU, Pierre (1980), "Le capital social: notes provisoires". Actas de la recherche en sciences sociales, v. 31, pp. 2-3 [Consult. 10-09-2018]. Disponível em http://capitalintelectual.egc.ufsc.br/wpcontent/uploads/2016/05/bourdieu_capital_social-1.pdf

BOURDIEU, Pierre (2003), "Algumas Propriedades do Campo", in P. Bourdieu, Questões de Sociologia. Lisboa: Fim de Século, pp. 119-126.

BRANDÃO, Camila D. (2014), Fatores intervenientes na implementação de ações estratégicas para a promoção do selo de Indicação Geográfica das panelas de barro de Goiabeiras. Dissertação de Mestrado apresenta ao Programa de Pós-Graduação em Administração - Universidade Federal do Espírito Santo - Vitória.

CAMILETTI, Giovana G. (2012), "Modernidade e Tradição em Anthony Giddens: um Olhar sobre os Estilos de Vida nas Paneleiras de Goiabeiras". Revis. Interdis. de Gest. Soc.- RIGS, v. 1, n. 2, pp. 165188 [Consult. 19-08-2018]. Disponível em https://periodicos.ufba.br/index.php/rigs/article/view/10067

COELHO, Claudio M. (2007). Gilberto Freyre: indiciarismo, emoção e política na casa grande e na senzala. Dissertação defendida no Programa de Pós-graduação em História Social das relações Políticas. CCHN, UFES. Vitória.

DAGNINO, Evelina (2004), "Sociedade Civil, participação e cidadania: do que estamos falando?", in D. Mato (coord.). Políticas de ciudadanía y sociedade civil em tempos de globalización: Caracas, FACES, Universidade Central de Venezuela, pp. 95-110.

DIAS, Carla (2006), Panela de Barro Preta: a tradição das Paneleiras de Goiabeiras, Vitória - ES. Rio de Janeiro, Muad X: Facitec.

DOMINGUES, Mauro P; PALASSI, Márcia P; GONÇALVES, Alyne S. (2011), "Introdução e Metodologia", in M. Zorzal e Silva, M. Palassi, A. Gonçalves. (Orgs). "Trajetórias redes e poderes: aspectos da articulação entre sociedade civil e sociedade política no estado do Espírito Santo sob o discurso do sujeito coletivo". Sinais, n. 10, pp. 01-14 [Consult. 02-02-2016]. Disponível em https://periodicos.ufes.br/sinais/article/view/2809

DOSSIÊ IPHAN 3 (2006), Ofício das Paneleiras de Goiabeiras. Brasília, DF, IPHAN.

GOHN, Maria da G. (2005), O protagonismo da sociedade civil: movimentos sociais, ONGs e redes solidárias. São Paulo, Cortez.

GOVERNO DO ESTADO DO ESPÍRITO SANTO. Decreto $n^{\circ}$ 3690-E, de 25 de janeiro de 1988. Declara de utilidade pública para fins de desapropriação área de terra destinada à implantação de Estação de Tratamento de Esgoto Sanitário. Diário Oficial do Estado do Espírito Santo, Vitória, 26 jan.

GOVERNO DO ESTADO DO ESPÍRITO SANTO. Lei $n^{\circ}$ 5.566, de 31 de Dezembro de 1997. Declara de utilidade pública a Associação das Paneleiras de Goiabeiras. Vitória.

GUINZBURG, Carlos (1989), Mitos, emblemas, sinais: morfología e história. São Paulo, Cia. das Letras.

HOBSBAWN, Eric (1984), "Introdução: a invenção das tradições", in E. Hobsbawn e T. Ranger (Orgs). A invenção das tradições. Rio de Janeiro, Paz e Terra, pp. 9-23. 
KLIKSBERG, Bernardo (1999), "Capital social y cultura, claves esenciales del desarrollo". Revis. de la CEPAL, n. 69, pp. 85-102 [Consult. 25-06-2018]. Disponível em https://www.cepal.org/es/publicaciones/12190-capital-social-cultura-claves-esenciales-desarrollo

LIMA, Jacob C. (2001), “A teoria do capital social na análise de políticas públicas”. Polít. \& Trab., n, 17, $\begin{array}{lllll}\text { pp. } & \text { [Consult. } & \text { 25-06-2018]. } & \text { Disponível } & \text { em }\end{array}$ https://periodicos.ufpb.br/ojs/index.php/politicaetrabalho/article/view/6481

MARQUES, Marcelo de S. (2020), "As Paneleiras de Goiabeiras Velha: Uma Análise Discursiva do Processo de Construção do Território da Tradição". Revista Brasileira de Sociologia - SBS, v. 8, n. 18, pp. 212-238 [Consult. 05-04-2020]. Disponível em http://www.sbsociologia.com.br/rbsociologia/index.php/rbs/article/view/521/pdf_60

MARQUES, Marcelo de S.; CALOTI, Vinicius A. (2013), "As Paneleiras de Goiabeiras e a dinâmica da Cultura do Barro". Sociologia, n. XXVI, pp.163-185 [Consult. 04-06-2016]. Disponível em http://www.scielo.mec.pt/pdf/soc/v26/v26a08.pdf

MINGO JR., N. (2000), Goiabeiras. Vitoria (ES), Secretaria Municipal de Cultura.

MOISÉS, José Álvaro (2008), "Cultura política, instituições e democracia: lições da experiência brasileira". Rev Bras. Cien. Soc., v. 23, n. 66, pp. 11-44 [Consult. 05-09-2018]. Disponível em https://www.scielo.br/pdf/rbcsoc/v23n66/02.pdf

NICOLE, Braz. C.; NASCIMENTO, Josué. C.; MARQUES, Marcelo de S.; COSTA, Matheus, H. T.; PEREIRA, Pedro H. M.; PRADO, Rodrigo V.; CALOTI, Vinicius A. (2012), "As paneleiras de Goiabeiras e a arte de fazer panela de barro: Ensaio etnográfico sobre a cultura do barro". Simbiótica, v. $1, \quad$ n. 1 , pp. 16-52 [Consult. 17-10-2018]. Disponível em http://periodicos.ufes.br/simbiotica/article/view/4524/3528

NORA, Pierre (1993), Entre memória e História: a problemática dos lugares. Proj. História, n. 10, pp. 0728 [Consult. 21-11-2018]. Disponível em https://revistas.pucsp.br/index.php/revph/article/view/12101

PATEMAN, Carole (1992), "O sentido de eficácia política e a participação no local de trabalho", in C. Pateman, Participação e Teoria Democrática. Rio de Janeiro, Paz e Terra, pp. 93-114.

PEROTA, Celso; BELING NETO, Roberto A.; DOXSEY, Jaime R. (1997), Paneleiras de Goiabeiras. Vitória, Secretaria Municipal de Cultura.

PINTO, Celi (2004), “A sociedade civil institucionalizada". Polít. \& Soci., n. 5, pp. 99-116 [Consul. 0210-2018]. Disponível em https://doi.org/10.5007/\%25x

PREFEITURA MUNICIPAL DE VITÓRIA (2008). Lei $n^{\circ}$ 3.944, de Julho de 1993. Institui no Município de Vitória o "Dia das Paneleiras". Câmara Municipal, Legislação Online.

PULICE, Gabriel M. F.; ZELIS, Oscar (2011), "La Práctica de la Investigacíon en relacíon al Pensamiento Mágico, la Conjectura, el Paradigma Indiciário y la ciencia Moderna: notas para repensar la cientificidade". Revista Eletrónica de Epistemología de Ciências Sociales, n. 12.

PUTNAM, Robert (1995), "Bowling Alone: America's declining social capital”. Journal of Democracy, v. 6, n. 1, pp. 65-78 [Consult. 06-02-2018]. Disponível em 10.1353/jod.1995.0002

PUTNAM, Robert (2000), Comunidade e democracia: a experiência da Itália moderna. $5^{\text {a }}$ ed. Rio de Janeiro, Ed. da FGV. 
REIS, Bruno P. W. (2003), "Capital social e confiança: questões de teoria e método". Revis. Sociol. e Polit., Curitiba, n. 21, pp. 83-108 [Consult. 03-02-2018]. Disponível em https://www.scielo.br/pdf/rsocp/n21/a04n21.pdf

RENNÓ, Lúcio (1998), Teoria da Cultura Política: vícios e virtudes. BIB, Rio de Janeiro, n. 45, pp. 71-92 [Consult. 10-11-2018]. Disponível em https://www.anpocs.com/index.php/bib-pt/bib-45/486-teoriada-cultura-politica-vicios-e-virtudes/file

RIEDL, Mario; VOGT, Olgário P. (2003), "Associativismo e Desenvolvimento: considerações sobre a existência de capital social", in S. M. S Correa (Org.). Capital Social e desenvolvimento regional. Santa Cruz do Sul: EDUNISC, pp. 149-211.

RODRIGUES, Marcia B. (2005), "Razão e sensibilidade: reflexões em torno do paradigma indiciário". Dimensões, n. 17, pp. 213-221.

RUBIÃO, André (2010), “Apresentação: o 'grand soir' da democracia”, in Y. Sintomer, O poder ao povo: júris de cidadãos, sorteio e democracia participativa. Belo Horizonte, Editora UFMG, p. 13-20.

SAINT-HILAIRE, August (1974), Viagem ao Espírito Santo e Rio Doce. Belo Horizonte, Itatiaia/USP.

SIMÃO, Luciene M. (2008), A semântica do intangível: considerações sobre o Registro do ofício das Paneleiras do Espírito Santo, Tese de Doutorado apresentada ao Programa de Pós-Graduação em Antropologia - Universidade Federal Fluminense - Niterói. 


\begin{abstract}
This article aims to reflect on the mobilization of social capital and the development of an associativeparticipatory political culture around the Association of the Paneleiras de Goiabeiras (APG), Vitória-ES. The hypothesis holds that the process of creating the APG was not successful in the mobilization of social capital and did little to contribute to the development of participatory practices within the institution. These practices could lead to greater involvement and identification of those associated with the APG. The methodology consisted of qualitative techniques, specifically bibliographic research and interviews. The result indicates that the APG construction process negatively impacted the local social capital, generating a perception of "institutional mistrust" and "low associativism / involvement" considering the association.
\end{abstract}

Keywords: social capital; political culture; Association of the Paneleiras de Goiabeiras (APG).

\title{
Resumen
}

El objetivo de este artículo es reflexionar sobre la movilización del capital social y sobre el desarrollo de una cultura política asociativa-participativa en relación con la Asociación de las Paneleiras de Goiabeiras (APG), Vitória-ES. La hipótesis sostiene que el proceso de creación de la APG no logró éxito en la movilización del capital social y poco contribuyó para el desarrollo de prácticas participativas dentro de la institución, prácticas que podrían proporcionar mayor implicación e identificación de los asociados con la APG. La metodología consistió en técnicas cualitativas, específicamente investigación bibliográfica y entrevistas en profundidad. Los resultados indican que el proceso de construcción de la APG impactó negativamente en el capital social local, generando una percepción de "desconfianza institucional" y "bajo asociatividad / implicación" con relación a la asociación.

Palabras clave: capital social; cultura política; Asociación de las Paneleiras de Goiabeiras (APG). 